\title{
Evaluation of a taurine containing amino acid solution in parenteral nutrition
}

\author{
L Thornton, E Griffin
}

\begin{abstract}
Vaminolact, an amino acid solution containing taurine, was given to 15 sick newborn babies. They were compared with a group of 10 babies who received a solution that did not contain taurine (Vamin glucose). Efficacy and safety were evaluated by monitoring plasma amino acid patterns, growth patterns, nitrogen balance, and biochemical and haematological profiles. No serious abnormalities in amino acid concentrations were found. After an initial fall the taurine concentration recovered more rapidly in those receiving the taurine supplement, though this difference was not significant. Phenylalanine concentrations were within the reference range in the group receiving Vaminolact, and were significantly lower than in the group receiving Vamin glucose. Metabolic acidosis, which occurred in several subjects in each group, was not a serious problem. Liver function tests remained satisfactory. Nitrogen retention was greater among those receiving Vaminolact than in the control group.
\end{abstract}

Vaminolact is a safe and effective amino acid solution for use in critically ill babies.

Total parenteral nutrition is now an integral part of the care of sick newborn infants, particularly those for whom enteral feeding is unsuitable becuase they have respiratory distress, gastrointestinal anomalies, or necrotising enterocolitis.

Recently, amino acid solutions specifically designed for neonates have been produced. Most, however, do not contain taurine, one of the amino acids present in human milk.

Taurine is an amino acid containing sulphur, which is one of the most abundant amino acids present in mammals. ${ }^{1}$ It is found in high concentrations in human milk, being second only to glutamate in concentration in the free amino acid pool of human milk. ${ }^{2}$ Until recently little was known about its function apart from its role in the conjugation of bile acids in the liver and its appearance as an end product of methionine and cysteine metabolism. More recent studies have pointed towards a physiological and pharmacological role for taurine in retinal and nervous tissues. ${ }^{1}$ There is now increasing evidence to suggest that taurine may be a conditionally essential amino acid-that is, a compound that is not essential for healthy people but which is required by sick people or immature infants. ${ }^{3}$

In a study of patients on long term parenteral nutrition with no taurine supplementation, Geggel et al found abnormal electroretinograms in the children examined. ${ }^{4}$ Addition of taurine to the parenteral nutrition solution restored the plasma taurine concentrations and the electroretinograms to normal. Plasma taurine concentrations fall rapidly in premature infants when parenteral nutrition without taurine supplementation is given. ${ }^{5}$

Vaminolact (KabiVitrum, sold as Vamin Infant in the United Kingdom) contains taurine $300 \mathrm{mg} / \mathrm{l}$, which is based on the content of taurine in human milk (table 1 ).

This study was designed to evaluate the suitability of Vaminolact as an amino acid solution containing taurine for the newborn receiving total parenteral nutrition. The efficacy was judged by monitoring plasma amino acid patterns (with particular reference to taurine), growth patterns, and nitrogen balance. The safety of the solution was monitored by measuring acid-base balance and plasma amino acid chromatograms as well as full blood counts and liver and kidney function during the course of treatment. Plasma amino acid concentrations, weight gain, nitrogen balance, and acid-base balance were compared with those of a group of newborns receiving total parenteral nutrition with a different amino acid solution, Vamin glucose (KabiVitrum) (table 1), which was the solution previously used in the neonatal intensive care unit.

\section{Patients and methods}

Twenty five consecutively newborn babies who were considered to require parenteral nutrition for a minimum of one week were studied. Informed consent was obtained from the parents in all cases. The treatment group con-

Table 1 Amino acid composition of Vaminolact and Vamin glucose

\begin{tabular}{lcc}
\hline & $\begin{array}{l}\text { Vaminolact } \\
(\mathrm{g} / \mathrm{l})\end{array}$ & $\begin{array}{l}\text { Vamin } \text { glucose } \\
(\mathrm{g} / \mathrm{l})\end{array}$ \\
\hline Glycine & $2 \cdot 1$ & $2 \cdot 1$ \\
L-Aspartic acid & $4 \cdot 1$ & $4 \cdot 1$ \\
L-Alanine & $6 \cdot 3$ & $3 \cdot 0$ \\
L-Arginine & $4 \cdot 1$ & $3 \cdot 3$ \\
L-Cysteine/cystine & $1 \cdot 0$ & $1 \cdot 4$ \\
L-Glutamic acid & $7 \cdot 1$ & $9 \cdot 0$ \\
L-Histidine & $2 \cdot 1$ & $2 \cdot 4$ \\
L-Isoleucine & $3 \cdot 1$ & $3 \cdot 9$ \\
L-Leucine & $7 \cdot 0$ & $5 \cdot 3$ \\
L-Lysine & $5 \cdot 6$ & 3.9 \\
L-Methionine & $1 \cdot 3$ & $1 \cdot 9$ \\
L-Phenylalanine & $2 \cdot 7$ & $5 \cdot 5$ \\
L-Proline & $5 \cdot 6$ & $8 \cdot 1$ \\
L-Serine & $3 \cdot 8$ & $7 \cdot 5$ \\
L-Threonine & $3 \cdot 6$ & $3 \cdot 0$ \\
L-Tryptophan & $1 \cdot 4$ & $1 \cdot 0$ \\
L-Tyrosine & $0 \cdot 5$ & $0 \cdot 5$ \\
L-Valine & $3 \cdot 6$ & $4 \cdot 3$ \\
Taurine & $0 \cdot 3$ & 0 \\
\hline Total & $65 \cdot 3$ & $70 \cdot 2$ \\
\hline
\end{tabular}


sisted of 15 babies who received Vaminolact as part of their regimen of total parenteral nutrition. The comparison group comprised the previous 10 babies who had received total parenteral nutrition with the same regimen, differing only in the amino acid solution used, which was Vamin glucose.

This investigation was not a randomised trial, as it was considered impossible for practical reasons to prepare and administer two different amino acid solutions in the special care unit at the same time.

A profile of each of the patients, including the indications for total parenteral nutrition, is given in table 2. Mean gestational age, birth weight, and mean age at starting total parenteral nutrition were similar in the two groups of babies (table 2). Apgar scores, maternal age, parity, and problems in pregnancy and labour were also similar between the groups, though duration of membrane rupture was significantly longer in the group receiving Vamin glucose $(\mathrm{p}=0.007)$.

The first five infants receiving Vaminolact were considered as a 'pilot' group, and had their taurine concentrations measured daily until they were stable on an intake of $2.5 \mathrm{~g} / \mathrm{kg} /$ day of amino acids. As soon as the taurine concentra- tions were satisfactory the study continued with the remaining 10 babies. The patients remained in the study until full gastrointestinal feeding had been established. Two of the infants receiving Vaminolact and one receiving Vamin glucose died during the study period, but the deaths were not related to the total parenteral nutrition. All the other infants completed the study.

\section{REGIMEN OF PARENTERAL NUTRITION}

The regimen provided carbohydrate, electrolyte, and amino acid solutions as well as lipid emulsion in gradually increasing quantities according to the age of the baby, up to a maximum daily intake of $200 \mathrm{ml} / \mathrm{kg}$ of fluid, $2 \cdot 5$ $\mathrm{g} / \mathrm{kg}$ of amino acid, $4 \mathrm{~g} / \mathrm{kg}$ of lipid (Intralipid $10 \%$ ) and a projected maximum caloric intake of $493.2 \mathrm{~kJ}(118 \mathrm{kcal}) / \mathrm{kg} /$ day. Trace elements (Ped-El) water soluble vitamins (Solivito) and fat soluble vitamins (Vitlipid Infant) (all KabiVitrum) were added according to recommended daily requirements. Solutions were given simultaneously by continuous pump infusion into a peripheral vein over a 24 hour period.

Infants were not withdrawn from the study until full enteral feeding was established.

Table 2 Data on newborn infants receiving total parenteral nutrition with Vamin glucose and Vaminolact

\begin{tabular}{|c|c|c|c|c|c|}
\hline Case No & $\begin{array}{l}\text { Gestational } \\
\text { age (weeks) }\end{array}$ & $\begin{array}{l}\text { Birth weight } \\
(\mathrm{g})\end{array}$ & $\begin{array}{l}\text { Age at start } \\
\text { (days) }\end{array}$ & $\begin{array}{l}\text { Indications for } \\
\text { total parenteral nutrition }\end{array}$ & $\begin{array}{l}\text { Duration of } \\
\text { total parenteral } \\
\text { nutrition (days) }\end{array}$ \\
\hline \multicolumn{6}{|c|}{$\begin{array}{l}\text { Infants receiving } \\
\text { Vamin glucose: }\end{array}$} \\
\hline 1 & $\begin{array}{l}40 \\
31\end{array}$ & $\begin{array}{l}2850 \\
1530\end{array}$ & $\begin{array}{l}3 \\
1\end{array}$ & $\begin{array}{l}\text { Necrotising enterocolitis } \\
\text { Preterm/respiratory distress } \\
\text { syndrome }\end{array}$ & $\begin{array}{r}10 \\
9\end{array}$ \\
\hline 3 & 29 & 1290 & 0 & $\begin{array}{l}\text { Preterm/respiratory distress } \\
\text { syndrome }\end{array}$ & 7 \\
\hline 4 & 31 & 1460 & 0 & $\begin{array}{l}\text { Preterm/respiratory distress } \\
\text { syndrome }\end{array}$ & 13 \\
\hline 5 & 30 & 1870 & 1 & $\begin{array}{l}\text { Preterm/respiratory distress } \\
\text { syndrome }\end{array}$ & 8 \\
\hline $\begin{array}{l}6 \\
7\end{array}$ & $\begin{array}{l}41 \\
31\end{array}$ & $\begin{array}{l}4000 \\
1500\end{array}$ & $\begin{array}{l}4 \\
0\end{array}$ & $\begin{array}{l}\text { Necrotising enterocolitis } \\
\text { Preterm/respiratory distress } \\
\text { syndrome }\end{array}$ & $\begin{array}{l}9 \\
7\end{array}$ \\
\hline 8 & 34 & 1840 & 1 & $\begin{array}{l}\text { Preterm/respiratory distress } \\
\text { syndrome }\end{array}$ & 9 \\
\hline $\begin{array}{r}9 \\
10\end{array}$ & $\begin{array}{l}29 \\
29\end{array}$ & $\begin{array}{l}695 \\
870\end{array}$ & $\begin{array}{l}1 \\
1\end{array}$ & $\begin{array}{l}\text { Preterm/very low birth weight } \\
\text { Preterm/respiratory distress } \\
\text { syndrome }\end{array}$ & $\begin{array}{l}18 \\
13\end{array}$ \\
\hline Mean (SD) & $32.5(4 \cdot 5)$ & $1790(980)$ & $1 \cdot 2(1 \cdot 3)$ & & $10(3)$ \\
\hline \multicolumn{6}{|c|}{ Infants receiving } \\
\hline 11 & 26 & 740 & 1 & $\begin{array}{l}\text { Preterm/respiratory distress } \\
\text { syndrome }\end{array}$ & 15 \\
\hline 12 & 26 & 740 & 1 & $\begin{array}{l}\text { Preterm/respiratory distress } \\
\text { syndrome }\end{array}$ & 23 \\
\hline $\begin{array}{l}13 \\
14 \\
15 \\
16\end{array}$ & $\begin{array}{l}32 \\
29 \\
40 \\
30\end{array}$ & $\begin{array}{l}1330 \\
1280 \\
2720 \\
1530\end{array}$ & $\begin{array}{l}0 \\
1 \\
3 \\
0\end{array}$ & $\begin{array}{l}\text { Preterm/low birth weight } \\
\text { Preterm/congenital heart disease } \\
\text { Necrotising enterocolitis } \\
\text { Preterm/respiratory distress } \\
\text { syndrome }\end{array}$ & $\begin{array}{r}9 \\
12 \\
10 \\
12\end{array}$ \\
\hline 17 & 30 & 1603 & 0 & $\begin{array}{l}\text { Preterm/respiratory distress } \\
\text { syndrome }\end{array}$ & 11 \\
\hline 18 & 29 & 1090 & 1 & $\begin{array}{l}\text { Preterm/respiratory distress } \\
\text { syndrome }\end{array}$ & 12 \\
\hline $\begin{array}{l}19 \\
20 \\
21\end{array}$ & $\begin{array}{l}30 \\
25 \\
31\end{array}$ & $\begin{array}{r}1470 \\
640 \\
1600\end{array}$ & $\begin{array}{l}1 \\
1 \\
1\end{array}$ & $\begin{array}{l}\text { Preterm/low birth weight } \\
\text { Preterm/very low birth weight } \\
\text { Preterm/respiratory distress } \\
\text { syndrome }\end{array}$ & $\begin{array}{r}7 \\
11 \\
10\end{array}$ \\
\hline 22 & 31 & 1100 & 1 & $\begin{array}{l}\text { Preterm/respiratory distress } \\
\text { syndrome }\end{array}$ & 23 \\
\hline 23 & 32 & 1800 & 1 & $\begin{array}{l}\text { Preterm/respiratory distress } \\
\text { syndrome }\end{array}$ & 9 \\
\hline 24 & 26 & 920 & 0 & $\begin{array}{l}\text { Preterm/respiratory distress } \\
\text { syndrome }\end{array}$ & 10 \\
\hline 25 & 29 & 1550 & 1 & $\begin{array}{l}\text { Preterm/respiratory distress } \\
\text { syndrome }\end{array}$ & 10 \\
\hline Mean (SD) & $29 \cdot 7(3 \cdot 6)$ & $1340(530)$ & $0.9(0.7)$ & & $12(5)$ \\
\hline
\end{tabular}




\section{MONITORING}

Routine monitoring was carried out with full blood counts, liver function tests, and estimations of serum concentrations of urea and electrolytes, glucose, acid-base values, magnesium, phosphorus, and triglycerides. Plasma amino acid analyses were performed before starting the study, after 24 hours of an intake of $2 \mathrm{~g} / \mathrm{kg}$ of amino acid, and again after three days on an intake of $2.5 \mathrm{~g} / \mathrm{kg} /$ day of amino acid. They were carried out weekly thereafter. The amino acid concentrations were measured by ion exchange chromatography with a Locarte amino acid analyser. Plasma ammonia concentrations were checked when the infant had been on an amino acid intake of $2.5 \mathrm{~g} / \mathrm{kg} /$ day for two days.

Urine was collected for estimation of 24 hour nitrogen balance on an amino acid intake of $2 \mathrm{~g}$ and $2.5 \mathrm{~g} / \mathrm{kg} / \mathrm{day}$. Because of difficulties in collecting urine specimens it was not possible to calculate nitrogen balance for all the infants. Samples were analysed for nitrogen content by Tingvall's method. ${ }^{6}$ In calculating the nitrogen balance an extra $25 \%$ of the urinary nitrogen output was added as an estimate of the faecal nitrogen loss. ${ }^{7}$

Body weight was recorded daily, unless contraindicated by instability of the infant's condition.

\section{STATISTICAL ANALYSIS}

The significance of differences in proportions was assessed by Fisher's exact test. All quantitative and ordinal variables were examined by the Wilcoxon two sample test for independent data. A p value of $<0.05$ was accepted as significant.

\section{Results}

PLASMA AMINO ACIDS

Table 3 shows the mean plasma amino acid concentrations in the two groups before starting the infusion of amino acid solution, and on intakes of $2 \mathrm{~g} / \mathrm{kg} /$ day and $2.5 \mathrm{~g} / \mathrm{kg} /$ day of amino acids.
Transient hypertyrosinaemia $(>196 \mu \mathrm{mol} / \mathrm{l})$ occurred in four infants, three receiving Vamin glucose and one receiving Vaminolact. ${ }^{8}$ In two infants it resolved spontaneously and in the remaining two it resolved after additional vitamin $\mathrm{C}$ had been given.

One baby on Vaminolact, who had congenital heart disease and cardiac failure (table 2, case 14), had total parenteral nutrition withheld for 28 hours from day 4 because of a mildly raised glutamine concentration $(1032 \mu \mathrm{mol} / \mathrm{l})$.

There were no other abnormalities in amino acid concentrations that necessitated treatment or change in the total parenteral nutrition regimen.

\section{TAURINE CONCENTRATIONS}

In both groups of infants the taurine concentrations were lower on an amino acid intake of 2 $\mathrm{g} / \mathrm{kg} /$ day than before the infusion, but the concentrations rose again when the intake was increased to $2 \cdot 5 \mathrm{~g} / \mathrm{kg} /$ day (fig 1 ). Compared with the group receiving Vamin glucose the mean taurine concentration before infusion was lower in the group receiving Vaminolact, but the

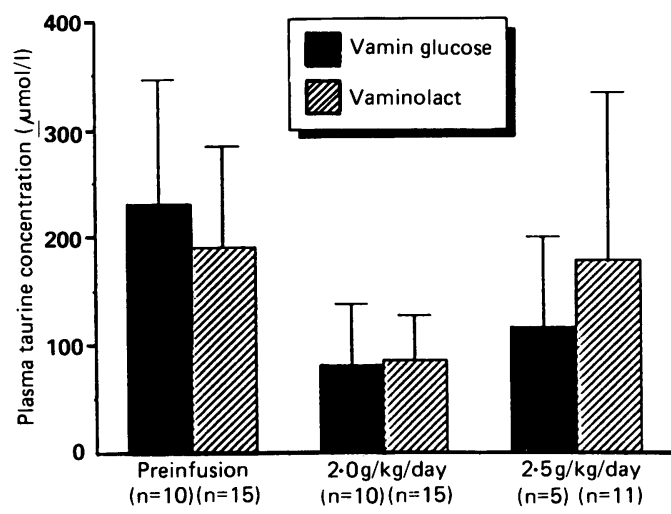

Figure 1 Mean (SD) plasma taurine concentrations before treatment, and during infusions of $2 \cdot 0 \mathrm{~g} / \mathrm{kg} /$ day, and $2 \cdot 5$ g/kg/day.

Table 3 Mean (SD) plasma amino acid concentrations ( $\mu m o l / l$ )

\begin{tabular}{|c|c|c|c|c|c|c|}
\hline & \multicolumn{2}{|l|}{ Before infusion } & \multicolumn{4}{|c|}{ Projected amino acid intake } \\
\hline & \multirow{2}{*}{$\begin{array}{l}\text { Vamin } \\
\text { glucose }\end{array}$} & \multirow[t]{2}{*}{ Vaminolact } & \multicolumn{2}{|l|}{$2 \cdot 0 \mathrm{~g} / \mathrm{kg} / \mathrm{day}$} & \multicolumn{2}{|l|}{$2 \cdot 5 \mathrm{~g} / \mathrm{kg} /$ day } \\
\hline & & & $\begin{array}{l}\text { Vamin } \\
\text { glucose }\end{array}$ & Vaminolact & $\begin{array}{l}\text { Vamin } \\
\text { glucose }\end{array}$ & Vaminolact \\
\hline $\begin{array}{l}\text { Actual amino acid } \\
\text { intake }(\mathrm{g} / \mathrm{kg} / \mathrm{day})\end{array}$ & Not applicable & Not applicable & $1 \cdot 9+0 \cdot 1$ & $1 \cdot 8+0 \cdot 2$ & $2 \cdot 3+0 \cdot 1$ & $2 \cdot 3+0 \cdot 2$ \\
\hline $\begin{array}{l}\text { Taurine } \\
\text { Aspartic acid } \\
\text { Threonine } \\
\text { Serine } \\
\text { Glutamine } \\
\text { Glutamic acid } \\
\text { Glycine } \\
\text { Alanine } \\
\text { Valine } \\
\text { Cystine } \\
\text { Methionine } \\
\text { Isoleucine } \\
\text { Leucine } \\
\text { Tyrosine } \\
\text { Phenylalanine } \\
\text { Lysine } \\
\text { Ornithine } \\
\text { Histidine } \\
\text { Tryptophan } \\
\text { Arginine }\end{array}$ & $\begin{array}{r}230(117) \\
19(11) \\
145(79) \\
111(27) \\
225(86) \\
85(76) \\
261(86) \\
214(67) \\
76(15) \\
25(8) \\
41(15) \\
40(9) \\
69(15) \\
118(71) \\
72(19) \\
159(62) \\
62(33) \\
123(34) \\
37(13) \\
25(27)\end{array}$ & $\begin{aligned} 190(95) \\
22(13) \\
144(86) \\
110(38) \\
436(231)^{* * *} \\
51(39) \\
290(129) \\
204(85) \\
115(56)^{*} \\
44(15)^{* * *} \\
39(13) \\
56(17)^{* * *} \\
68(19) \\
94(38) \\
75(33) \\
144(52) \\
48(20) \\
115(28) \\
40(24) \\
37(24)\end{aligned}$ & $\begin{array}{c}79(58) \\
34(28) \\
162(50) \\
221(69) \\
312(170) \\
136(157) \\
305(74) \\
257(175) \\
156(32) \\
45(15) \\
46(16) \\
76(21) \\
122(26) \\
296(323) \\
143(51) \\
200(74) \\
83(42) \\
142(29) \\
48(29) \\
35(27)\end{array}$ & $\begin{aligned} 85(43) \\
30(20) \\
244(91)^{* * *} \\
179(61) \\
492(216) \\
41(38) \\
277(98) \\
202(61) \\
149(39) \\
56(15) \\
42(13) \\
70(18) \\
133(41) \\
81(101)^{* * *} \\
78(28)^{* * *} \\
223(97) \\
83(39) \\
135(31) \\
62(42) \\
63(59)\end{aligned}$ & $\begin{aligned} 114(84) \\
31(31) \\
152(41) \\
211(38) \\
329(141) \\
159(111) \\
292(84) \\
233(101) \\
180(17) \\
43(13) \\
58(19) \\
91(17) \\
115(22) \\
116(61) \\
147(41) \\
131(59) \\
53(20) \\
142(39) \\
38(8) \\
40(11)\end{aligned}$ & $\begin{aligned} & 177(156) \\
& 43(44)(12) \\
& 310(122)^{* *} \\
& 235(84) \\
& 480(126) \\
& 22(34)^{* *} \\
& 387(76) \\
& 326(126) \\
& 181(58) \\
& 79(28)^{* *} \\
& 50(20) \\
& 86(38) \\
& 166(56) \\
& 51(31)^{* *} \\
& 98(53) \\
& 253(63)^{* * *} \\
& 97(43) \\
& 138(28) \\
& 62(41) \\
& 48(47)\end{aligned}$ \\
\hline
\end{tabular}

Vamin glucose compared with Vaminolact: ${ }^{*} \mathrm{p}<0.05,{ }^{* *} \mathrm{p}<0.02$, and ${ }^{* * *} \mathrm{p}<0.01$. 
mean concentrations on infusions of $2 \mathrm{~g}$ and $2.5 \mathrm{~g}$ were higher in the group receiving Vaminolact though this difference was not significant.

Taurine concentrations exceeded the upper limit of the reference range $(256 \mu \mathrm{mol} / \mathrm{l}$, suggested by Clayton $e t a l^{8}$ ) in two babies who were receiving Vaminolact. Both were extremely ill at the time, one with congenital heart disease and cardiac failure and the other with sepsis and intraventricular haemorrhage (table 2, cases 14 and 20), and both died soon afterwards, the deaths being unrelated to total parenteral nutrition. In both cases the concentrations of other amino acids were also raised.

Taurine concentrations measured daily on the first five babies receiving Vaminolact were all satisfactory except in the case of case 14 in whom it was mildly increased on two occasions (fig 2).

OTHER BIOCHEMICAL DATA

Several babies in each group had raised creatinine concentrations. This was not unexpected as these infants all had patent ductus arteriosus and fluids were being restricted.

One infant in each group had a mildly raised plasma ammonia concentration $(<140 \mu \mathrm{mol} / \mathrm{l})$. As both infants had started (the following day) enteral feeds by the time the result was reported, however, no alteration was made in the total parenteral nutrition regimen.

There were no abnormalities in liver function tests. Serum proteins were low in many cases, but this is expected in sick premature infants.

Six babies receiving Vaminolact and three receiving Vamin glucose developed metabolic

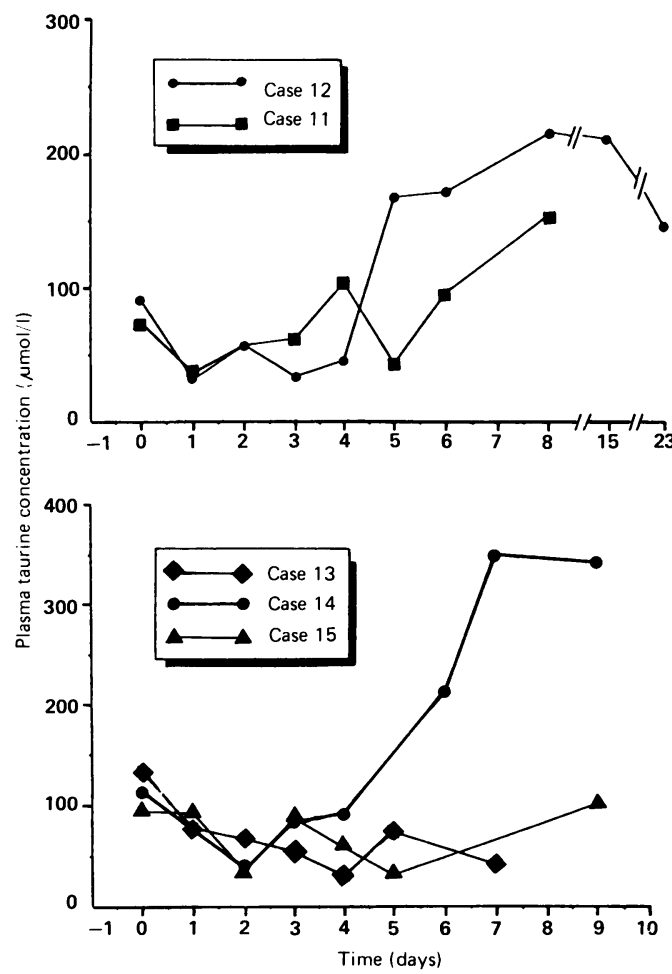

Figure 2 Plasma taurine concentrations before and during infusion of Vaminolact in cases 11,12,13,14, and 15 (pilot group)

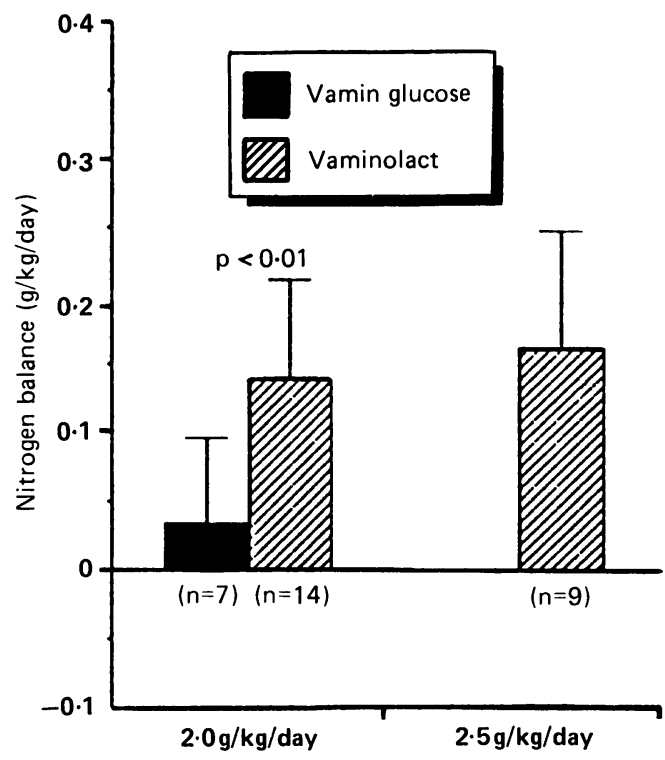

Figure 3 Mean $(S D)$ nitrogen balances during infusions of $2 \cdot 0 \mathrm{~g} / \mathrm{kg} /$ day and $2.5 \mathrm{~g} / \mathrm{kg} /$ day.

acidosis. In the case of five babies (two receiving Vaminolact and three receiving Vamin glucose) the acidosis was unexplained by sepsis but the episode was brief in all cases and responded to treatment with bicarbonate. Some small babies needed daily maintenance doses of bicarbonate. In some babies the total parenteral nutrition regimen was altered. In the group receiving Vaminolact the amino acid solution was stopped for one baby for 24 hours, and for three days for the baby who subsequently died of sepsis. In the group receiving Vamin glucose the solution was stopped for a few hours of one infant, and for another infant it was decided not to increase the intake of amino acids to $2.5 \mathrm{~g} / \mathrm{kg} /$ day because of acidosis. In one receiving Vaminolact the acidosis was accompanied by mild increases in threonine, isoleucine, and leucine concentrations.

\section{NITROGEN BALANCE}

The mean nitrogen balance on amino acid intakes of $2 \mathrm{~g}$ and $2.5 \mathrm{~g} / \mathrm{kg} /$ day for the two groups of infants are shown in fig 3 . Nitrogen retention on an intake of $2 \mathrm{~g} / \mathrm{kg} /$ day was significantly higher among those receiving Vaminolact, but no such comparison could be made on the higher intake as nitrogen balance was estimated in only one infant receiving Vamin glucose.

\section{BODY WEIGHT}

Most infants lost weight within the first few days, and in many cases this weight loss was compounded by fluid restriction which was instituted because of patent ductus arteriosus. Of the 15 subjects receiving Vaminolact, five regained their birth weight by day 7 to 11 while on total parenteral nutrition. Four babies receiving Vamin glucose regained their birth weight by day 4 to 17 on total parenteral nutrition. 


\section{Discussion}

The purpose of this study was to assess the efficacy and safety of Vaminolact as an amino acid solution containing taurine for use in neonates. Studies of low birthweight infants who have been fed a variety of formulas with and without taurine support the indication that there is a dietary requirement for taurine in rapidly growing infants. ${ }^{9} 10$ The main pathway for the biosynthesis of taurine is through methionine, cysteine, cysteine sulphinic acid, and hypotaurine. ${ }^{11}$ This pathway does not seem to become fully active until some time after full term. Cystathionase is absent during fetal development. ${ }^{10}$ In human tissues, particularly those of neonates, only trace amounts of cysteine sulphinic acid decarboxylase are present. ${ }^{1}$

Although this study was not randomised, the groups were comparable for all the variables examined except duration of membrane rupture.

No serious abnormalities in amino acid concentrations were observed. Bearing in mind the short term nature of the study, the plasma taurine concentrations attained on Vaminolact were encouraging. After an initial fall from the value before infusion, the taurine concentration showed a more rapid recovery after infusion of Vaminolact than of Vamin glucose, although this difference was not significant. Follow up of one patient who required more prolonged total parenteral nutrition indicated a levelling out of the taurine concentration at an acceptable and non-toxic level. Griffin and Gray in their study of Vaminolac (Vaminolact without taurine), also showed this fall followed by a rise in taurine concentration. ${ }^{12}$ The mean taurine concentration reached on an amino acid intake of 2.5 $\mathrm{g} / \mathrm{kg} /$ day in their study was lower than in the group receiving taurine supplementation of the present study.

Phenylalanine concentrations were within the reference range with Vaminolact and were lower than in the Vamin glucose group. Neither group of subjects developed the hyperphenylalaninaemia that has recently been a cause of concern in parenterally fed newborns. ${ }^{13}$

One baby (of 31 weeks' gestation) had a raised tyrosine concentration that resolved spontaneously. In the control group three infants whose gestational age at birth ranged from 29 to 31 weeks developed raised tyrosine concentrations. Dickinson et al in their study of low birthweight newborn babies, found raised tyrosine concentrations in many babies, and discussed the association of tyrosinaemia with developmental immaturity. ${ }^{14}$

Recent studies have suggested that taurine deficiency may be associated with the development of cholestasis in experimental animals, and one study of three children on total parenteral nutrition without taurine supports the theory that taurine deficiency produces cholestasis in humans, and is possibly associated with the development of the severe hepatic dysfunction that sometimes develops on patients receiving total parenteral nutrition. ${ }^{15}$ Liver function tests were satisfactory in both groups in this study, but a longer study period would be necessary to investigate the effect of taurine supplementation in the prevention of hepatic dysfunction associated with total parenteral nutrition.

Nitrogen balance where assessed was predominantly positive, and there was greater nitrogen retention in infants given Vaminolact than in those given Vamin glucose.

In many cases, energy intake was lower than intended and weight gain was less than predicted. In most of them this was the result of the necessity to restrict fluids in patients with patent ductus arteriosus, or because of delay in starting Intralipid because of jaundice of prematurity. Several babies had regained their birth weight, and most showed a positive trend in this direction before the end of the study period.

We found Vaminolact to be a safe and effective amino acid solution for use in critically ill, but stable, babies. Any problem that we did encounter, as outlined above, would not be unexpected in a group of small and sick infants such as those in the study. There remains the need for extreme vigilance when using total parenteral nutrition in neonates, however, not only with regard to taurine, but also to tyrosine and phenylalanine, so frequent monitoring is essential. Ill septic infants have a reduced ability to clear amino acids and particular care must be taken in this group when these solutions are being given.

We thank the nursing and medical staff of the neonatal unit Coombe Lying-In Hospital; Drs P Deasy and E Tempany; and the Biochemistry Departments at Coombe Lying-In Hospital The Children's Hospital, Temple St, and Our Lady's Hospita for Sick Children, Crumlin, for their help and cooperation during the study. The amino acid solutions were supplied by KabiVitrum. LT was supported by Coombe Hospital Development Trust.

1 Sturman JA, Hayes KC. The biology of taurine in nutrition and development. In: Draper HH, ed. Advances in nutritional research. Vol 3. New York: Plenum Press, 1980: 231-300.

2 Rassin DK, Sturman JA, Gaull GE. Taurine and other free amino acids in the milk of man and other mammals. Early Hum Dev 1978;2:1-13.

3 Gaull GE. Taurine in human milk: growth modulator or conditionally essential amino acid? $\mathcal{F}$ Pediatr Gastroenterol Nutr 1983;2(suppl 1):266-71.

4 Geggel HS, Ament ME, Heckenlively JR, Martin DA Kopple JD. Nutritional requirement for taurine in patients receiving long-term parenteral nutrition. $N$ Engl f Med 1985;312:142-6.

5 Cooke RJ, Whitington PF, Kelts D. Effects of taurine supplementation on hepatic function during short-term parenteral nutrition in the premature infant. $\mathcal{F}$ Pediatr Gas troenterol Nutr 1984;3:234-8.

6 Tingvall P. Determination of nitrogen with copper as catalys for high-temperature digestion. Analyst 1978;103:406-9.

7 Anderson TL, Muttart CR, Bieber MA, Nicholson JF, Heird WC. A controlled trial of glucose versus glucose and amino acids in premature infants. F Pediatr 1979;94:947-51.

8 Clayton BE, Jenkins P, Round JM Paediatric chemical pathology: clinical tests and reference ranges. Oxford: Blackwell Scientific Publications, 1980:30.

9 Rigo J, Senterre J. Is taurine essential for the neonates? Biol Neonate 1977;32:73-6.

10 Gaull GE, Rassin DK, Raiha NC, Heinonen K. Milk protein quantity and quality in low birth-weight infants. III Effects quantity and quality in low birth-weight infants. II Effects on sulfur amino

11 Jacobsen JG, Smith LH. Biochemistry and physiology of taurine and taurine derivatives. Physiol Rev 1968;48: 424-511.

12 Griffin EA, Gray PH. A study evaluating the metabolism of Vaminolac in the sick preterm infant. Acta Chir Scand 1983;517(suppl):89-101

13 Puntis JW, Edwards MA, Green A, Morgan I, Booth IW Ball PA. Hyperphenylalaninaemia in parenterally fed newborn babies. Lancet 1986; ii: 1105-6.

14 Dickinson JC, Rosenblum H, Hamilton PB. Ion exchange chromatography of the free amino acids in the plasma of infants under $2500 \mathrm{~g}$ at birth. Pediatrics 1970;45:606-13.

15 Cooper A, Betts JM, Pereira GR, Ziegler MM. Taurine deficiency in the severe hepatic dysfunction complicating total parenteral nutrition. $\mathcal{f}$ Pediatr Surg 1984;19:462-6. 